\title{
UPAYA MENINGKATKAN KETERAMPILAN MENYIMAK CERITA ANAK MELALUI PENGGUNAAN MEDIA BONEKA PADA KELOMPOK B1 TK BUSTANUL ATHFAL AISYIYAH BULAKAN SUKOHARJO
}

\section{TAHUN AJARAN 2016/2017}

\author{
Dian Deki Damara ${ }^{1}$, M. Ismail Sriyanto ${ }^{2}$, Ruli Hafidah ${ }^{1}$ \\ ${ }^{1}$ Program Studi PG PAUD/ Universitas Sebelas Maret \\ ${ }^{2}$ Program Studi PGSD/ Universitas Sebelas Maret
}

Email :diandeki09@gmail.com, ismail@fkip.uns.ac.id, ruli_hafidah@yahoo.com

\begin{abstract}
ABSTRAK:
Tujuan penelitian untuk meningkatkan keterampilan menyimak cerita anak melalui penggunaan media boneka pada kelompok B1 TK Bustanul Athfal Aisyiyah Bulakan Tahun Ajaran 2016/2017.Penelitian tindakan kelas yang menggunakan pendekatan kualitatif dan kuantitatif.Dilaksanakan melalui dua siklus, setiap siklus terdiri dari empat tahap yaitu perencanaan, pelaksanaan, observasi dan refleksi. Subyek penelitian adalah anak usia 5-6 tahun yang berjumlah 34 anak. Sumber data dari anak, guru dan aktivitas pembelajaran selama kegiatan menyimak cerita anak.Teknik pengumpulan data diperoleh melalui observasi, wawancara, dokumentasi dan tes.Peneliti menggunakan uji validitas kuantitatif konstruk, validitas kualitatif triangulasi sumber dan teknik. Teknik analisis data kuantitatif menggunakan kuantitatif komparatif dan analisis data kualitatif menggunakan model interaktif yang meliputi pengumpulan data, reduksi data, tampilan data dan penarikan kesimpulan. Hasil penelitian menunjukkan melalui penggunaan media boneka, anak dapat menjawab pertanyaan mengenai isi cerita dan dapat menceritakan kembali secara runtut cerita anak. Ketuntasan secara klasikal pada pratindakan sebesar 35,3\% atau 12 anak mencapai kriteria tuntas, siklus I meningkat sebesar 56\% atau 19 anak mencapai kriteria tuntas dan siklus II mengalami peningkatan sebesar 88,2\% atau 30 anak mencapai kriteria tuntas. Hasil penelitian menunjukkan bahwa penggunaan media boneka dapat meningkatkan keterampilan menyimak cerita anak pada anak kelompok B1 TK Bustanul Athfal Aisyiyah Bulakan Tahun Ajaran 2016/2017.
\end{abstract}

Kata Kunci: Keterampilan menyimak, cerita anak, media boneka

\section{ABSTRACT:}

The aim of research to improve the skills of listening to children's stories through the puppet media in the kindgather groups B1 Bustanul Athfal Aisyiyah Kindergather Bulakan of the year 2016/2017. Classroom action research using qualitative and quantitative approaches. Implemented through two cycles, each cycle consists of four stages of planning, implementation, observation and reflection. The subjects of the study were children aged 
5-6 years, amounting to 34 children. Data source from children, teachers and learning activities during the activities of listening to children's stories. Data collecting technique obtained through observation, interviews, documentation and tests. The Research used quantitative validity test of construct, qualitative validity of source triangulation and technique. Quantitative data analysis techniques use quantitative comparative and qualitative data analysis using interactive methods which cover reduction, data collect, data display and conclution. The results showed through the use of puppet media, the child can answer questions about the story and can be told in a coherent manner. The classically completeness at $35.3 \%$ or 12 children reeach diligence terion, the first cycle increased by $56 \%$ or 19 children achieving complete criteria and the second cycle increased by $88.2 \%$ or 30 children achieving complete criteria. The results showed that the use of puppet media can increase listening skills children's stories in children group B1 Bustanul Athfal Aisyiyah KindergatherBulakan of the year 2016/2017.

Keywords: Listening skills, children's stories, puppet media 


\section{PENDAHULUAN}

Masa kanak-kanak awal (early childhood) merupakan periode perkembangan yang terjadi mulai akhir masa bayi hingga sekitar usia lima atau enam tahun kadang periode ini disebut tahun prasekolah (Santrock, 2007: 20). Menurut Permendikbud nomor 146 tahun 2014 anak usia dini ditunjukan kepada anak sejak lahir sampai dengan usia enam tahun. Periode emas ini hanya berlangsung satu kali sepanjang rentang kehidupan manusia. Masa ini sangat mempengaruhi keberhasilan pada masa berikutnya. Seorang anak membutuhkan rangsanganrangsangan pada masa golden age yang tepat untuk mencapai kematangan yang sempurna, oleh karena itu dibutuhkan sebuah stimulasi bagi pendidikan anak usia dini yang tepat (Pratisti, 2008: 56). Aspek perkembangan anak harus dikembangkan sedini mungkin guna untuk mencapai tujuan perkembangan yang optimal ketahap usia selanjutnya.

Perkembangan bahasa merupakan sebagai salah satu dari kemampuan dasar yang harus dimiliki anak (Dhieni, 2011: 3.1) pentingnya perkembangan bahasa akan mempengaruhi kemampuan komunikasi anak dalam kehidupan seharihari. Anak dapat berkomunikasi dengan baik apabila dilakukan stimulasi agar perkembangan bahasa anak bisa berkembang lebih optimal. Keterampilan bahasa mencangkup empat segi yaitu keterampilan menyimak, keterampilan berbicara, keterampilan membaca, dan keterampilan menulis (Tarigan, 2008:2). Keterampilan bahasa anak diperoleh ketika anak belajar menyimak kemudian baru belajar berbicara, membaca, dan menulis. Keempat keterampilan tersebut salah satunya yang perlu dikembangkan untuk anak usia dini adalah keterampilan menyimak.

Oduolowu \& Oluwakemi (2014: 100) mengungkapkan, bahwa menyimak adalah keterampilan bahasa pertama anak-anak yang berkembang dan keterampilan komunikasi yang paling dominan dalam kelas dan kehidupan sehari-hari. Pentingnya menyimak dalam interaksi komunikatif memang sangat nyata. Seseorang yang terlibat dalam suatu komunikasi harus mampu memahami dan mereaksi suatu hal yang baru saja dikatakan. Sehingga, pembelajaran perlu melatih keterampilan menyimak, anak bisa memperoleh kosakata dan gramatikal, di samping itu tentunya pengucapan yang baik. Oleh karena itu, kegiatan menyimak perlu dipusatkan dan dikembangkan sedini mungkin karena sebagai dasar pengembangan kemampuan berbahasa lainnya.

Berdasarkan hasil wawancara dan 
observasi yang telah dilakukan pada tanggal 13 Desember 2016 dan 18 Januari 2017 pada guru kelompok B1 TK Bustanul Athfal Aisyiyah Bulakan, ditemukan permasalahan dalam perkembangan bahasa yaitu masih rendahnya kemampuan dalam menyimak cerita pada anak. Hasil tes yang dilakukan pada 18 Januari 2017 dalam keterampilan menyimak cerita anak terlihat $61,8 \%$ dari 34 anak kurang memahami isi cerita saat dilakukan tanya jawab tentang isi cerita, anak kurang memahami dan salah menjawab pertanyaan tentang isi cerita anak yang berupa tema cerita, nama tokoh, sifat tokoh dalam cerita, tempat, waktu, dan pesan yang terkandung dalam isi cerita anak. Menyimak berkaitan dengan proses mengingat, sebanyak 64,7\% anak kurang optimal dalam kegiatan menceritakan kembali isi cerita, alur cerita saat anak unjuk kerja masih terbalik-balik sehingga memerlukan bantuan guru dalam menceritakan kembali isi cerita yang telah diperdengarkan. Faktor rendahnya keterampilan menyimak karena anak tidak memperhatikan dan mendengarkan guru saat kegiatan bercerita sehingga proses pembelajaran menyimak cerita tidak berjalan optimal, misalnya beberapa anak ada yang mengobrol dengan temannya atau tidak memperhatikan guru dengan memainkan tangan atau kakinya.

Guru pada dasarnya sudah melakukan berbagai upaya untuk mengasah keterampilan menyimak kepada anak-anak agar nantinya ketika anak sudah mulai memahami sebuah isi cerita. Namun upaya yang sudah dilakukan oleh pihak sekolah belum sepenuhnya memberikan dampak yang memuaskan bagi perkembangan keterampilan menyimak anak, karena sebagian besar anak belum tertarik terhadap media guru yang digunakan saat bercerita. Melihat kurang optimalnya keterampilan anak dalam menyimak sebuah cerita pada usia lima sampai enam tahun di sekolah menjadikan bahan pertimbangan perlunya sebuah solusi untuk mengatasi permasalahan ini mengingat bahwa keterampilan anak dalam menyimak cerita pada usia lima hingga enam tahun tengah berkembang.

Konsep pembelajaran yang lebih bermakna terutama dalam mengasah keterampilan menyimak cerita pada anak yang disesuaikan dengan kriteria pembelajaran anak yang masih bersifat kongkret maka diperlukan sebuah media dalam pembelajaran. Penggunaan media sangatlah penting dalam pembelajaran pada anak usia dini khususnya di TK, 
karena anak memang membutuhkan suatu media yang dapat anak lihat secara langsung sehingga anak bisa menangkap pembelajaran dengan lebih jelas (Lindsay \&Nancy, 2013: 439-446). Media digunakan untuk menarik perhatian anak agar terpusat pada permbelajaran yang sedang berlangsung.

$$
\text { Belfiore }
$$

(2013:

mengungkap- kan untuk anak-anak TK boneka adalah alat yang sederhana dan efektifuntuk menyampaikan informasi, ketika boneka berbicara anak-anakdapat mendengarkan, mengidentifikasi, memahami kata-kata dan frase yang dilakukan oleh guru dengan penekanan yang tegas, tepat ucapan, dan pengucapannya. Penggunaan puppet (boneka) menjadi salah satu cara yang dapat diterapkan dalam pembelajaran. Sehingga keterampilan menyimak pada anak merupakan hal yang penting, dikarenakan keterampilan menyimak cerita berkaitan dengan kemampuan mengingat, berkomunikasi, dan berbicara.

\section{Keterampilan Menyimak Cerita Anak}

Keterampilan bagi anak bagi anak salah satunya adalah menyimak, menyimak merupakan mendengarkan dengan pemahaman, mengingat yang kemudian diinterprestasikan (Caspersz \& Stasinska, 2015: 1). Menyimak digunakan untuk berkomunikasi dalam kehidupan sehari-hari, jadi perlu adanya stimulasi keterampilan menyimak sejak dini. Pem- belajaran di TK yang sering dilakukan adalah bercerita, melalui pembelajaran tersebut dapat dijadikan stimulasi bagi anak untuk meningkatkan keterampilan menyimak dengan memper- dengarkan sebuah cerita anak dari guru. Madyawati (2016: 164) menjelaskan bahwa cerita anak merupakan karya sastra yang ditunjukkan kepada anak-anak. Cerita tersebut yang ditulis untuk anak yang berbicara mengenai kehidupan disekeliling anakanak yang dapat mempengaruhi perilaku anak dan cerita itu hanya dapat dinikmati oleh anak dengan bantuan dan pengarahan orang dewasa agar menumbuhkan moral yang positif ketika anak mendengarkan cerita anak tersebut. Sehingga dapat diketahui bahwa keterampilan menyimak cerita anak adalah adalah suatu kemampuan berpikir dan mengingat dalam proses mendengarkan simakan untuk memahami dan menginterpretasikan simakan secara lisan yang terkandung dalam cerita anak yang telah diperdengarkan secara lisan melalui kata-kata yang bersifat menyenangkan dan mengandung nilai moral bagi anak.

\section{Media Boneka}


Media pembelajaran tiga dimensi yang tidak dapat diproyeksikan dan disajikan secara visual. Klasifikasi media ini dapat terwujud dalam benda asli maupun tiruan. Media tiga dimensi ini sering digunakan guru dalam proses pembelajaran, karena media ini mudah didapat dan mudah menarik perhatian anak.

Menurut Madyawati (2016: 185) boneka bukan hal yang asing bagi dunia bermain anak, boneka juga digunakan sebagai media pembelajaran disekolahsekolah. Pemilihan media boneka disesuaikan dengan usia dan pengalaman anak, boneka yang digunakan mewakili tokoh manusia dan hewan. Boneka biasanya berwujud dari ayah, ibu, anak laki-laki dan anak perempuan, nenek, kakek dan bisa ditambahkan anggota keluarga yang lain (Moeslichatoen, 2005: 159). Boneka juga dapat buat dan dibentuk sesuai dengan materi pembelajaran yang akan disampaikan kepada anak. Penggunaan bermacam jenis boneka dapat membangkitkan antusias anak dalam mengikuti pembelajaran, anak akan lebih senang dan tertarik untuk mendengarkan cerita pengumpulan data meliputi observasi, wawancara, dokumentasi dan tes yang berupa unjuk kerja. Penelitian ini menggunakan teknik analisis data melalui penggunaan media boneka. Belfiore (2013: 9) menngungkapka bahwa boneka dapat bergerak yang dikendalikan dengan senar, batang atau dengan menempatkan satu tangan didalam tubuh boneka.Jadi, media boneka adalah sebuah media yang berwujud benda mati yang dapat dilihat secara visual yang menyerupai manusia, hewan dan tumbuhan yang diberi suara dan digerakkan oleh pemainnya melalui senar, batang atau dengan satu tangan yang masuk ke tubuh boneka.

\section{METODE}

Penelitian dilaksanakan di TK Bustanul Athfal Aisyiyah Bulakan dengan subyek berjumlah 34 anak usia 5- 6 tahun. Penelitan ini menggunakan penelitian kuantitatif dan kualitatif dengan jenis penelitian tindakan kelas (PTK) yang dilakukan di dalam kelas yang bermasalah.Terdapat dua siklus, setiap siklus terdiri dari empat tahapan yaitu perencanaan, pelaksanaan, observasi dan refleksi. Peneliti menggunakan uji validitas kuantitatif konstruk dan uji validitas kualitatif interaktif. Teknik

kuantitatif komparatif dan analisis data kualitatif interaktif. 
HASIL PENELITIAN DAN

PEMBAHASAN

Keterampilan menyimak cerita anak melalui penggunaan media boneka pada kelompok B1 TK Bustanul Athfal Aisyiyah Bulakan mengalami peningkatan yang signifikan pada pratindakan, siklus 1, dan siklus II

Tabel 1 hasil nilai keterampilan menyimak cerita anak

\begin{tabular}{lllllll}
\hline \multirow{2}{*}{ Nilai } & \multicolumn{2}{l}{ Pratindakan } & \multicolumn{3}{l}{ Siklus I } & \multicolumn{3}{l}{ Siklus II } \\
\cline { 2 - 7 } & Fi & Total & Fi & Total & Fi & Total \\
\hline 25 & 6 & 150 & 1 & 25 & 0 & 0 \\
37,5 & 4 & 148,8 & 6 & 223,2 & 0 & 0 \\
50 & 12 & 500 & 8 & 400 & 0 & 0 \\
62,2 & 0 & 0 & 0 & 0 & 4 & 250 \\
75 & 1 & 75 & 8 & 600 & 11 & 825 \\
87,5 & 11 & 962,5 & 11 & 962,5 & 12 & 1050 \\
100 & 0 & 0 & 0 & 0 & 7 & 700 \\
\hline Total & 34 & 2910,7 & 34 & 1058,2 & 34 & 2850 \\
\hline Rata-rata & $=54$ & & $=65$ & & $=83$ & \\
\hline
\end{tabular}

Pada tabel 1 data awal mendapat hasil yang rendah yaitu hanya 12 anak yang tuntas. Setelah kegiatan menyimak cerita anak melalui penggunaan media boneka yang dilakukan selama 2 siklus diperoleh peningkatan yang signifikan yaitu sebanyak 30 anak dikatakan tuntas.

Anak yang mencapai nilai $\geq 75$ berarti anak masuk pada kategori tuntas, sedangkan anak yanng memperoleh nilai di bawah 75 anak masuk kategori belum tuntas. Anak yang mendapatkan nilai 2562,2 dengan jumlah 4 anak dinyatakan bahwa anak belum terampil dalam menyimak cerita anak, selanjutnya anak yang mendapatkan nilai 75-87,5 dengan jumlah 23 anak dinyatakan terampil dalam menyimak cerita anak dan nilai 100 dengan jumlah 7 anak dinyatakan sangat terampil dalam menyimak cerita anak. Maka secara klasikal dapat diperoleh sebanyak 30 anak mengalami ketuntasan nilai sesuai yang diharapkan oleh peneliti yaitu mendapat nilai $\geq 75$.

Penggunaan berbagai jenis media boneka digunakan dalam setiap pertemuan dalam dua siklus, tujuannya agar anak tidak mudah bosan dan tetap 
antusias dalam mengikuti pembelajaran menyimak cerita dan ketika dilakukan tes unjuk kerja, anak mampu menjawab pertanyaan dan representasi cerita dengan optimal. Siklus I peneliti menggunakan boneka gagang, boneka gantung, boneka tempel, selanjutnya siklus II peneliti menggunakan boneka jari, boneka tangan, dan boneka utuh.

Peningkatan secara signifikan keterampilan menyimak cerita anak dari hasil pratindakan hingga siklus II melalui penggunaan media boneka saat guru bercerita sejalan dengan penelitian yang dilakukan Divtahari,dkk. (2015: 3) Menunjukkan bahwa melalui penggunaan media boneka saat guru bercerita dapat membuat suasana kelas menjadi menyenangkan, dengan menggunakan media boneka dalam mendengarkan cerita anak akan membuat suasana lebih berkonsentrasi pada cerita yang akan disampaikan karena mampu untuk menarik minat anak, anak tidak cepat bosan dalam mendengarkan cerita karena penggunaan media yang menarik, dan anak antusias dalam mengikuti pembelajaran menyimak cerita anak. Guru dapat melakukan tes tanya jawab dan representasi tentang isi cerita yang telah disampaikan pada anak. Melalui tes tersebut guru dapat mengetahui tingkat perkembangan keterampilan menyimak anak.

Penggunaan media saat bercerita pada pratindakan, siklus I hingga siklus II anak mampu memahami isi cerita anak mampu menjawab pertanyaan tentang isi cerita yang berupa tokoh yang ada dalam cerita, karakter tokoh dalam cerita anak, tempat atau setting, tema cerita anak, amanat atau pesan yang terkandung dalam cerita anak, dan menceritakan kembali sesuai dengan alur cerita. Penggunaan media saat pembelajaran bercerita pada anak dapat menstimulasi keterampilan menyimak anak seperti yang diungkapkan Oduolowu \& Oluwakemi (2014: 102). Kegunaan media saat bercerita membantu anak untuk mengingat dan memahami isi cerita yang disampaikan oleh guru. Selanjutnya menurut Caganaga \& Calmis (2015: 3) penggunaan media boneka dapat digunakan sebagai media mengajar bagi guru untuk meningkatkan perkembangan bahasa anak. Kosakata anak bertambah saat mendengarkan cerita dari guru, setelah kegiatan bercerita maka guru anak bertanya pada anak tentang isi cerita, maka anak akan menjawab dengan kosakata baru yang sudah didengar oleh anak ketika mendnegarkan cerita.

Berdasarkan hasil siklus II pertemuan 3 menunjukkan, sejumlah 4 
anak yang belum tuntas pada representasi cerita. Berdasarkan fakta selama observasi, tindakan dan wawancara terhadap guru dapat disimpulkan faktor yang mempengaruhi tidak tuntasnya anak yaitu faktor internal yaitu setiap anak atau penyimak dalam kemampuan menyimak sebuah cerita berbeda-beda dalam mencapai tingkat pemahaman cerita secara runtut. Hal tersebut sejalan dengan pendapat Hermawan (2012: 50) yang berupa keterbatasan anak dalam menerima simakan secara serentak atau kelebihan input (masukan), dengan banyaknya bahan atau topik yang diterima anak atau penyimak cenderung lupa ketika harus menceritakan kembali hasil simakan yang telah didengarkan.

Berdasarkan penelitian yang telah dilakukan dapat dikatakan bahwa melalui penggunaan media boneka dalam meningkatkan keterampilan menyimak cerita anak pada kelompok B1 TK Bustanul Athfal Aisyiyah Bulakan tahun ajaran 2016/2017, pembelajaran yang diberikan kepada anak lebih bermakna dan menarik. Anak lebih antusias dalam mendengarkan saat guru bercerita di depan kelas. Penggunaan media boneka suatu benda yang dapat dilihat secara langsung oleh anak dengan bentuknya yang menarik, berwarna-warni dan lucu, hal tersebut sesuai dengan pendapat Caganaga \& Kalmis (2015: 3). Anak juga memperoleh pengalaman baru saat pembelajaran bercerita, anak secara langsung dapat melihat guru menggunakan media boneka.Penggunaan media boneka yang berupa simbol-simbol dalam sumber media belajar, anak lebih mudah mengingat setiap tokoh dan alur cerita yang disimak anak, hal tersebut sesuai dengan pendapat Oduolowu \& Oluwakemi (2014: 100). Sehingga, melalui penggunaan media boneka dapat meningkatkan keterampilan menyimak cerita anak pada kelompok B1 TK Bustanul Athfal Aisyiyah Bulakan tahun ajaran 2016/2017.

Faktor lain yang mempengaruhi penggunaan media boneka dapat meningkatkan keterampilan menyimak cerita anak adalah belum digunakannya media boneka dalam pembelajaran bercerita, bentuk media boneka yang membuat minat, menarik perhatian anak ketika pembelajaran dan anak lebih antusias dalam mengikuti pembelajaran sehingga guru lebih mudah mengkondisikan anak dalam kegiatan menyimak cerita anak. Manfaat dari keterampilan menyimak adalah dapat mengasah daya ingat anak, menambah kosakata anak setelah mendengarkan 
cerita dan komunikasi anak lebih interaktif dengan guru maupun teman sekelas.

\section{PENUTUP}

Penggunaan media boneka dapat meningkatkan keterampilan menyimak cerita anak pada anak kelompok B1 TK Bustanul Athfal Aisyiyah Bulakan tahun ajaran 2016/2017. Melalui penggunaan media boneka menarik perhatian anak dalam kegiatan menyimak cerita sehingga mampu meningkatkan keterampilan menyimak cerita anak secara optimal. Peningkatan keterampilan menyimak cerita anak ditunjukkan dengan meningkatkanya nilai rata-rata anak dan ketuntasan nilai yang dicapai anak dalam setiap pertemuan selama dua siklus. Siklus pertama terdiri dari tiga pertemuan dengan hasil nilai belum mencapai kriteria ketuntasan yaitu sebesar 56\% dan siklus kedua terdiri dari tiga pertemuan yang mengalami peningkatan dengan hasil mencapai kriteria ketuntasan secara klasikal yaitu sebesar $88,3 \%$.

\begin{tabular}{lcr}
\multicolumn{2}{c}{ Guru dapat } & \multicolumn{2}{r}{ memberikan } \\
pembelajaran & pada anak dengan \\
menggunaan & media pada & saat \\
pembelajaran & berlangsung. & Sekolah \\
diharapkan & untuk ke depannya \\
memberikan & \multicolumn{2}{c}{ kesempatan dan }
\end{tabular}

memfasilitasi bagi guru untuk mengguna- kan media yang menarik. Peneliti selanjutnya bisa melakukan penelitian lebih lanjut sehingga bisa menambah referensi penelitian mengenai media boneka.

\section{DAFTAR PUSTAKA}

Belfiore, C. (2013, January/February). Puppets talk, Children Listen How Puppets Are Effective Aids For Kids. $\quad$ pp. 12.

http://connection.ebscohost.com/c /articles/91631978/puppetstalk- children-listen.

Caganaga, C. K., \& Kalmis, A. (2015). The Role of Puppets in Kindergarten Education in Cyprus. Open Access Library Journal, 1-9.

Dhieni, N., \& Fridani, L. (2011). Metode Pengembangan Bahasa. Jakarta: Universitas Terbuka.

Divtahari, I. G., Ni Ketut, S., \& P.A., D. (2015). Penerapan Metode Bercerita Berbantuan Media Boneka Untuk Meningkatkan Kemampuan Menyimak Anak. $e$ Journal PG PAUD Universitas Pendidikan Ganesha, (3) 1. 
Hermawan, H. (2012). Menyimak Keterampilan Berkomunikasi Yang Terabaikan. Yogyakarta: Graha Ilmu.

Lindsay, D. R., \& Nancy, V. K. (2013). Preschool Teachers and Children's Emergent Writing: Supporting Diverse Learners. Early Childhood Educ J, 41: 439446.

Madyawati, L. (2016). Strategi Pengembangan Bahasa Pada Anak. Jakarta: Prenadamedia Group.

Mendikbud. (2014).Permendikbud. Jakarta.
Moeslichatoen, R. (2005). Metode Pengajaran di Taman Kanakkanan. Jakarta: Rineka Cipta.

Oduolowu, E. \&. (2014). Effect of storytelling on listening skills of primary one pupil in Ibadan North Local Government Area of Oyo State, Nigeria. International Journey of Humanities and Social Science, vol 4:, 100-107.

Pratisti Dinar, W. (2008). Psikologi Anak Usia Dini. Surakarta: PT. Macanan Jaya Cemerlang.

Santrock, W. J. (2013). Perkembangan Anak. Jakarta: Penerbit Erlangga.

Tarigan, H. G. (2008). Menyimak Sebagai Suatu Keterampilan Berbahasa. Bandung: Angkasa. 